\title{
ANALISIS GAYA LATERAL PADA TIANG AKIBAT PENAMBAHAN TIMBUNAN DI PROYEK JALAN TOL JAKARTA
}

\author{
Marcello Dicky Wijaya $^{1}$, Aniek Prihatiningsih ${ }^{2}$ dan Josephine Aristiti Setyarini ${ }^{3}$ \\ ${ }^{1}$ Program Studi Sarjana Teknik Sipil, Universitas Tarumanagara, Jl. Letjen S. Parman No.1 Jakarta \\ Email: marcellodickywijaya@gmail.com \\ ${ }^{2}$ Program Studi Sarjana Teknik Sipil, Universitas Tarumanagara, Jl. Letjen S. Parman No.1 Jakarta \\ Email: aniekprihatiningsih@gmail.com \\ ${ }^{3}$ Program Studi Sarjana Teknik Sipil, Universitas Tarumanagara, Jl. Letjen S. Parman No.1 Jakarta \\ Email: Josephine.setyarini@gmail.com
}

\begin{abstract}
ABSTRAK
Pada salah satu jalan tol di Jakarta menggunakan konstruksi pile slab tiang pancang sepanjang $200 \mathrm{~m}$. Tiang yang digunakan adalah tiang spun pile beridameter $600 \mathrm{~mm}$. Tiang akan dipancang sampai ke tanah keras dengan dengan rentang kedalaman $12 \mathrm{~m}$ sampai $15 \mathrm{~m}$ dan memiliki free standing tiang setinggi $5 \mathrm{~m}$ diatas tanah eksisting. Ketinggian timbunan ini beragam, mulai dari $1 \mathrm{~m}$ hingga $4 \mathrm{~m}$ diatas tanah eksisting. Metode analisis yang digunakan untuk menghitung besarnya perpindahan horizontal dalam penulisan ini adalah metode elemen hingga. Berdasar pada hasil analisis, pemberian timbunan ini terbukti dapat meningkatkan tahanan lateral tiang sehingga perpindahan horizontal pada tiang semakin kecil. Pemberian timbunan $1 \mathrm{~m}$ sudah dapat meningkatkan tahanan lateral sebesar $78 \%$. Kajian secara teknis pemberian timbunan dengan ketinggian $1 \mathrm{~m}$ sampai $4 \mathrm{~m}$ ini pun dapat dikatakan aman ditinjau dari perpindahan horizontal dan momen yang terjadi pada tiang. Namun pemberian timbunan setinggi $4 \mathrm{~m}$ ini dapat dikatakan tidak efisien karena tahanan lateral tiang jauh lebih besar daripada beban lateral yang ada.
\end{abstract}

Kata kunci: fondasi tiang, tiang pancang, perpindahan horizontal, momen maksimum, timbunan

\section{PENDAHULUAN}

\section{Latar Belakang}

Fondasi tiang merupakan elemen struktur yang berfungsi untuk meneruskan beban ke tanah, baik beban aksial maupun beban lateral. Sebuah fondasi tiang harus memiliki tahanan atau daya dukung yang lebih besar dibandingkan dengan beban yang dipikulnya. Fondasi tiang juga dapat dibedakan menurut perilaku kepala tiang menjadi fondasi dengan free end dan fondasi fixed end. Pada fondasi free end, perpindahan horizontal dipengaruhi juga oleh jarak dari ujung tiang ke muka tanah. Semakin jauh jarak dari ujung tiang ke muka tanah maka semakin besar perpindahan horizontal yang akan terjadi. Untuk mengetahui besarnya perpindahan horizontal yang terjadi pada fondasi tiang dapat dilakukan dengan beberapa metode analisis, salah satunya adalah metode elemen hingga. Pada perancangan tiang dengan beban lateral, hasil pengujian besaran perpindahan horizontal yang terjadi ini menjadi tolok ukur keamanan tiang. Perpindahan horizontal yang terjadi pada sebuah tiang harus lebih kecil dari pada perpindahan horizontal yang diijinkan pada tiang tersebut. Salah satu upaya untuk mencegah terjadinya perpindahan horizontal yang berlebih adalah dengan menambahkan tanah timbunan di atas tanah existing seperti yang diterapkan pada proyek jalan tol ini. Oleh karena itu, dilakukan analisis untuk menentukan efektifitas timbunan terhadap perpindahan horizontal tiang.

\section{Batasan Masalah}

Dalam peneltitian ini, batasan-batasan yang digunakan sebagai berikut:

1. Parameter tanah akan dikorelasi berdasarkan data $\mathrm{N}_{\mathrm{SPT} \text {. }}$

2. Kajian terhadap defleksi tiang pancang akibat beban lateral.

3. Tiang yang ditinjau berdasarkan zona, yaitu tiang di PS-8 Kanan (Zona A), PS-14 Kanan (Zona B), PS-23 Kanan (Zona C), dan PS-27 Kanan (Zona D).

4. Sambungan antar tiang diasumsikan memiliki kekakuan yang sama, sehingga pada pemodelan dianggap sebagai satu cluster.

5. Efisiensi lateral tiang kelompok tidak dipertimbangkan. 
6. Material tanah menggunakan model mohr-coulomb.

7. Adanya perilaku tiang fixed head dan free head, dalam pemodelan digunakan perilaku tiang free head.

\section{Rumusan Masalah}

Rumusan masalah yang akan dibahas dalam penelitian ini adalah sebagai berikut:

1. Analisis perpindahan horizontal tanpa tanah timbunan

2. Analisis perpindahan horizontal dengan tanah timbunan

3. Analisa menggunakan program dengan metode finite element.

\section{Tujuan Penelitian}

Tujuan dari penelitian ini adalah untuk mengamati perilaku tiang pancang pada proyek jalan tol terhadap adanya timbunan di atas tanah eksisting berdasarkan analisis dengan menggunakan software metode finite element.

\section{Fondasi Tiang Pancang}

Fondasi tiang pancang adalah fondasi tiang yang telah dibuat terlebih dahulu sebelum dimasukan ke dalam tanah hingga mencapai kedalaman tertentu. Alat utama yang digunakan dalam fondasi tiang pancang adalah penumbuk (hammer) dan mesin derek (tower). Pemilihan penumbuk (hammer) yang tepat akan menempatkan tiang pada posisi yang tepat serta akan membuat waktu dan biaya menjadi lebih efisien. Maka itu kelebihan dan kekurangan penumbuk harus diperhatikan.

\section{Free Head Pile dan Fixed Head Pile}

Rahardjo (2017) menyebutkan dalam menganalisis, kondisi kepala tiang dibedakan menjadi kondisi kepala tiang bebas (free head) dan kepala tiang terjepit (fixed head). Kondisi kepala tiang bebas berarti bagian atas tiang bisa dengan bebas bergerak ke arah samping dan berputar ketika ada gaya geser atau momen. Sedangkan kondisi kepala tiang terjepit, bagian atas tiang boleh bergerak ke arah samping tetapi tidak diperbolehkan mengalami rotasi.

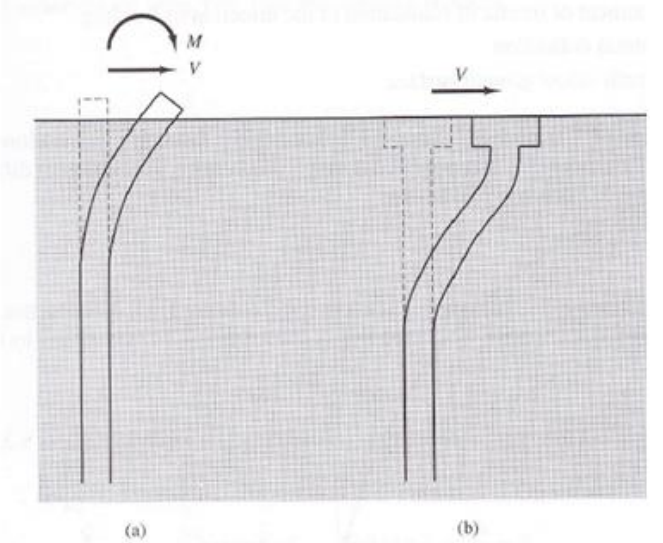

Gambar 1. Tipe Koneksi antara Tiang Dengan Struktur: (a) Free Head; (b) Fixed Head (Coduto, 2010)

\section{Perpindahan Horizontal Izin Tiang}

Berdasarkan Peraturan P2B No 50 Tahun 2007, ditentukan defleksi izin maksimum pada tiang free head sebesar 10 mm pada beban lateral 100\% dan $25 \mathrm{~mm}$ pada beban lateral 200\%, sedangkan dalam SNI 8460-2017 Persyaratan Perancangan Geoteknik pada subbab 9.7.3.1 mengenai kapasitas izin lateral tiang, disebutkan bahwa deformasi lateral izin tiang sebesar $12 \mathrm{~mm}$ untuk gempa rencana dan $25 \mathrm{~mm}$ untuk gempa kuat dalam kondisi tiang free head. 


\section{METODOLOGI PENELITIAN}

\section{Metode Pengumpulan Data}

Pada pengkajian teknis kali ini lokasi proyek yang ditinjau adalah salah satu proyek jalan tol di Jakarta. Data yang dikumpulkan adalah berdasarkan hasil peninjauan langsung di lapangan dengan melakukan pengamatan, pencatatan serta wawancara, sehingga data yang diperoleh sesuai. Data yang dikumpulkan antara lain adalah data hasil tes SPT (Standart Penetration Test) dan data pemancangan tiang dimana pada proyek kali ini digunakan tiang berdiameter $600 \mathrm{~mm}$ dengan jenis tiang pancang beton bertulang.

\section{Metode Analisis Data}

Sebelum dilakukannya analisis, dilakukan studi literatur terlebih dahulu unutk dapat memahami objek serta metodemetode yang akan diteliti. Studi literatur ini dilakukan melalui buku dan jurnal-jurnal. Hasil studi literatur ini digunakan sebagai landasan teori untuk mengkaji secara teknis pemancangan tiang serta mempelajari formulaformula dalam menghitung perpindahan horizontal tiang dan momen maksimum tiang. Metode analisis yang digunakan untuk menganalisa data menggunakan program berbasis metode elemen hingga. Analisis akan dilakukan dalam 2 kondisi, tanpa timbunan dan setelah pemberian timbunan. Hasil analisis berupa kurva hubungan antara beban dan perpindahan horizontal serta beban dan momen maksimum dengan berbagai tinggi timbunan. Dengan hasil kurva hubungan beban dan perpindahan horizontal akan dilakukan perbandingan daya dukung lateral fondasi tiang sebelum dan setelah pemberian timbunan dan diperoleh peningkatan daya dukung lateral fondasi tiang yang dipengaruhi oleh ketinggian timbunan.

\section{HASIL DAN PEMBAHASAN}

\section{Pembagian Zona}

Sebelum dilakukan analisis dan perhitungan defleksi lateral tiang pancang pada proyek jalan tol dilakukan pembagian zona berdasarkan pada lokasi titik borlog seperti pada Gambar 2. Adapun pembagian zona adalah sebagai berikut:

1. Zona A, BL47-RW5 terdiri dari PS 1 - PS 10

2. Zona B, BL47D terdiri dari PS 11 - PS 17

3. Zona C, BL47-RW4 terdiri dari PS 18 - PS 24

4. Zona D, BL47-RW3 terdiri dari PS 25 - PS 31

5. Zona E, BL47-RW2 terdiri dari PS 32 - PS 38

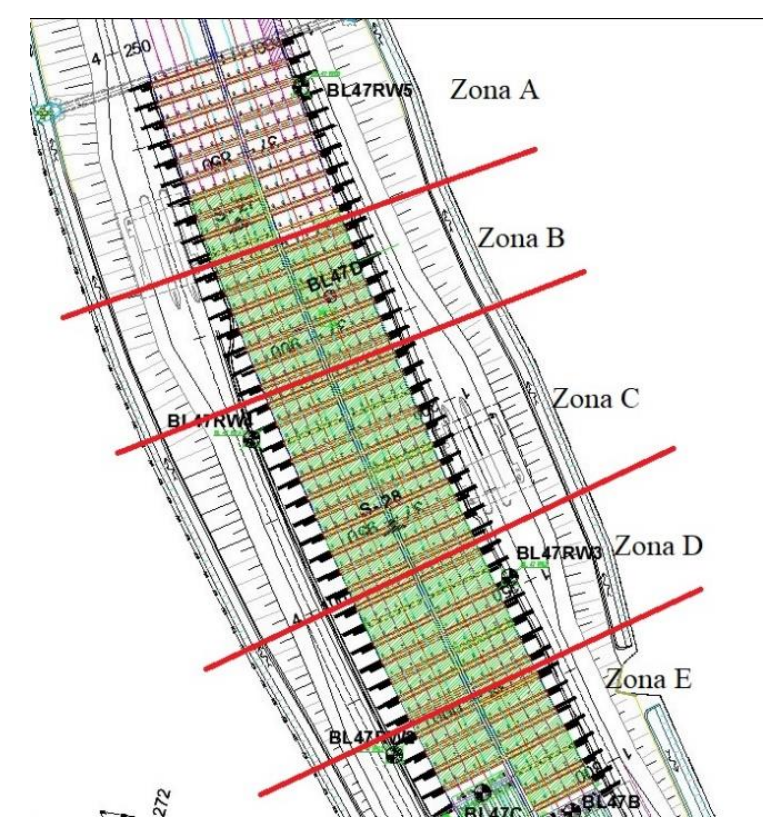

Gambar 2. Lokasi Pembagian Zona 


\section{Kesimpulan Parameter Tanah}

Proyek jalan tol ini memiliki empat titik bor sedalam 30 meter tanpa adanya hasil uji laboratorium. Oleh karena itu, beberapa parameter tanah yang diperlukan dalam proses analisis akan didapatkan melalui korelasi-korelasi dari data tanah yang ada. Penentuan parameter tanah berdasarkan zona-zona yang telah ditetapkan. Kesimpulan parameter tanah dapat dilihat pada Tabel 1. sampai Tabel 4.

Tabel 1. Kesimpulan Parameter Tanah Zona A (BL47-RW5)

\begin{tabular}{|c|c|c|c|c|c|c|c|c|}
\hline $\begin{array}{l}\text { Depth } \\
\text { (m) }\end{array}$ & $\begin{array}{l}\text { Soil } \\
\text { Type }\end{array}$ & $\begin{array}{c}\text { Soil } \\
\text { Consistency }\end{array}$ & $\begin{array}{c}\gamma \mathbf{s a t} \\
\left(\mathbf{k N} / \mathbf{m}^{3}\right)\end{array}$ & $\begin{array}{c}\mathrm{Su} \\
\left(\mathrm{kN} / \mathbf{m}^{2}\right)\end{array}$ & $\begin{array}{c}c^{\prime} \\
\left(k N / m^{2}\right)\end{array}$ & $\begin{array}{c}E^{\prime} \\
\left(k N / m^{2}\right)\end{array}$ & $\begin{array}{c}\phi \\
\left({ }^{0}\right)\end{array}$ & v \\
\hline $0-2$ & Silt & Hard & 19 & 160 & 30 & 40000 & 32 & 0.3 \\
\hline $2-4$ & Silt & Hard & 19 & 120 & 30 & 40000 & 32 & 0.3 \\
\hline $4-6$ & Silt & Hard & 19 & 100 & 30 & 40000 & 32 & 0.3 \\
\hline $6-10$ & Clay & Very Stiff & 19 & 100 & 20 & 23000 & 30 & 0.3 \\
\hline $10-12$ & Clay & Hard & 19 & 100 & 20 & 40000 & 30 & 0.3 \\
\hline $12-14$ & Silt & Hard & 19 & 100 & 20 & 40000 & 30 & 0.3 \\
\hline $14-16$ & Silt & Hard & 19 & 60 & 15 & 40000 & 30 & 0.3 \\
\hline $16-18$ & Silt & Very Stiff & 16 & 60 & 15 & 15000 & 30 & 0.3 \\
\hline $18-20$ & Silt & Very Stiff & 16 & 60 & 15 & 15000 & 30 & 0.3 \\
\hline $20-30$ & Clay & Very Stiff & 21 & 60 & 15 & 15000 & 30 & 0.3 \\
\hline
\end{tabular}

Tabel 2. Kesimpulan Parameter Tanah Zona B (BL47D)

\begin{tabular}{ccccccccc}
\hline $\begin{array}{c}\text { Depth } \\
(\mathbf{m})\end{array}$ & $\begin{array}{c}\text { Soil } \\
\text { Type }\end{array}$ & $\begin{array}{c}\text { Soil } \\
\text { Consistency }\end{array}$ & $\begin{array}{c}\boldsymbol{\gamma} \mathbf{s a t} \\
\left(\mathbf{k N} / \mathbf{m}^{\mathbf{3}}\right)\end{array}$ & $\begin{array}{c}\text { Su } \\
\left(\mathbf{k N} / \mathbf{m}^{\mathbf{2}}\right)\end{array}$ & $\begin{array}{c}\mathbf{c}^{\mathbf{\prime}} \\
\left(\mathbf{k N} / \mathbf{m}^{\mathbf{2}}\right)\end{array}$ & $\begin{array}{c}\mathbf{E}^{\mathbf{\prime}} \\
\left(\mathbf{k N} / \mathbf{m}^{\mathbf{2}}\right)\end{array}$ & $\begin{array}{c}\boldsymbol{\phi} \\
\left.\mathbf{(}^{\mathbf{0}}\right)\end{array}$ & $\mathbf{v}$ \\
\hline $0-2$ & Silt & Hard & 19 & 160 & 30 & 40000 & 32 & 0.3 \\
$2-4$ & Silt & Hard & 19 & 120 & 30 & 40000 & 32 & 0.3 \\
$4-6$ & Silt & Hard & 19 & 100 & 30 & 40000 & 32 & 0.3 \\
$6-10$ & Clay & Very Stiff & 19 & 100 & 20 & 23000 & 30 & 0.3 \\
$10-12$ & Clay & Hard & 19 & 100 & 20 & 40000 & 30 & 0.3 \\
$12-14$ & Silt & Hard & 19 & 100 & 20 & 40000 & 30 & 0.3 \\
$14-16$ & Silt & Hard & 19 & 60 & 15 & 40000 & 30 & 0.3 \\
$16-18$ & Silt & Very Stiff & 16 & 60 & 15 & 15000 & 30 & 0.3 \\
$18-20$ & Silt & Very Stiff & 16 & 60 & 15 & 15000 & 30 & 0.3 \\
$20-30$ & Clay & Very Stiff & 21 & 60 & 15 & 15000 & 30 & 0.3 \\
\hline
\end{tabular}

Tabel 3. Kesimpulan Parameter Tanah Zona C (BL47-RW4)

\begin{tabular}{|c|c|c|c|c|c|c|c|c|}
\hline $\begin{array}{l}\text { Depth } \\
\text { (m) }\end{array}$ & $\begin{array}{l}\text { Soil } \\
\text { Type }\end{array}$ & $\begin{array}{c}\text { Soil } \\
\text { Consistency }\end{array}$ & $\begin{array}{c}\gamma \mathbf{s a t} \\
\left(\mathbf{k N} / \mathbf{m}^{3}\right)\end{array}$ & $\begin{array}{c}\mathrm{Su} \\
\left(\mathrm{kN} / \mathbf{m}^{2}\right)\end{array}$ & $\begin{array}{c}c^{\prime} \\
\left(k N / m^{2}\right)\end{array}$ & $\begin{array}{c}\mathbf{E}^{\prime} \\
\left(k N / m^{2}\right)\end{array}$ & $\begin{array}{c}\phi \\
\left({ }^{\circ}\right)\end{array}$ & v \\
\hline $0-4$ & Silt & Very Stiff & 17 & 70 & 15 & 20000 & 30 & 0,3 \\
\hline $4-6$ & Silt & Very Stiff & 17 & 90 & 20 & 20000 & 30 & 0,3 \\
\hline $6-10$ & Silt & Hard & 19 & 150 & 20 & 30000 & 30 & 0,3 \\
\hline $10-12$ & Sand & Dense & 19 & 0 & 10 & 30000 & 42 & 0,3 \\
\hline $12-16$ & Sand & Dense & 19 & 0 & 10 & 30000 & 42 & 0,3 \\
\hline $16-18$ & Sand & Dense & 19 & 0 & 10 & 15000 & 42 & 0,3 \\
\hline $18-30$ & Clay & Very Stiff & 16 & 60 & 11 & 15000 & 30 & 0,3 \\
\hline
\end{tabular}

Tabel 4. Kesimpulan Parameter Tanah Zona D (BL47-RW5)

\begin{tabular}{|c|c|c|c|c|c|c|c|c|}
\hline $\begin{array}{l}\text { Depth } \\
\text { (m) }\end{array}$ & $\begin{array}{l}\text { Soil } \\
\text { Type }\end{array}$ & $\begin{array}{c}\text { Soil } \\
\text { Consistency }\end{array}$ & $\begin{array}{c}\gamma \mathbf{s a t} \\
\left(\mathbf{k N} / \mathbf{m}^{3}\right)\end{array}$ & $\begin{array}{c}\mathrm{Su} \\
\left(\mathrm{kN} / \mathbf{m}^{2}\right)\end{array}$ & $\begin{array}{c}c^{\prime} \\
\left(\mathrm{kN} / \mathrm{m}^{2}\right)\end{array}$ & $\begin{array}{c}\mathbf{E}^{\prime} \\
\left(k N / m^{2}\right)\end{array}$ & $\underset{\left({ }^{0}\right)}{\phi}$ & v \\
\hline $0-6$ & Clay & Medium Stiff & 15 & 30 & 5 & 7000 & 25 & 0,3 \\
\hline $6-8$ & Silt & Hard & 15 & 70 & 15 & 7000 & 25 & 0,3 \\
\hline $8-10$ & Silt & Hard & 19 & 70 & 15 & 7000 & 31 & 0,3 \\
\hline $10-20$ & Clay & Hard & 19 & 120 & 25 & 30000 & 31 & 0,3 \\
\hline $20-30$ & Clay & Very Stiff & 17 & 70 & 13 & 15000 & 30 & 0,3 \\
\hline
\end{tabular}




\section{Kajian Teknis Perpindahan Horizontal Tiang}

Pada kajian teknis perpindahan horizontal tiang akan dikaji hubungan antara besar beban lateral dan perpindahan horizontal yang terjadi untuk tiap tinggi timbunan pada tiap zona. Hubungan beban dan perpindahan horizontal tiap zona dapat dilihat pada Gambar 3. sampai Gambar 6.

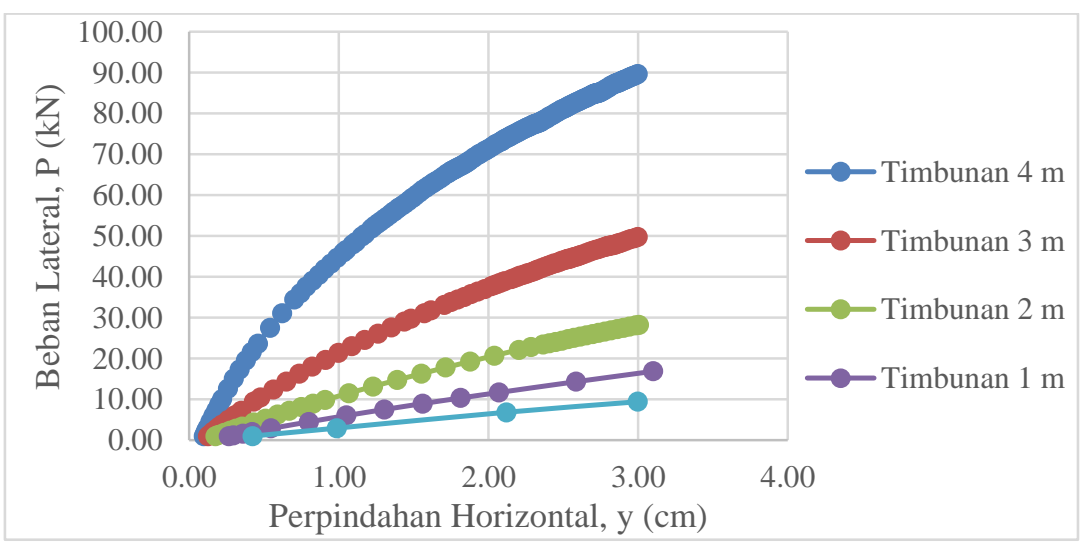

Gambar 3. Hubungan Beban dan Perpindahan Horizontal Tiang Zona A

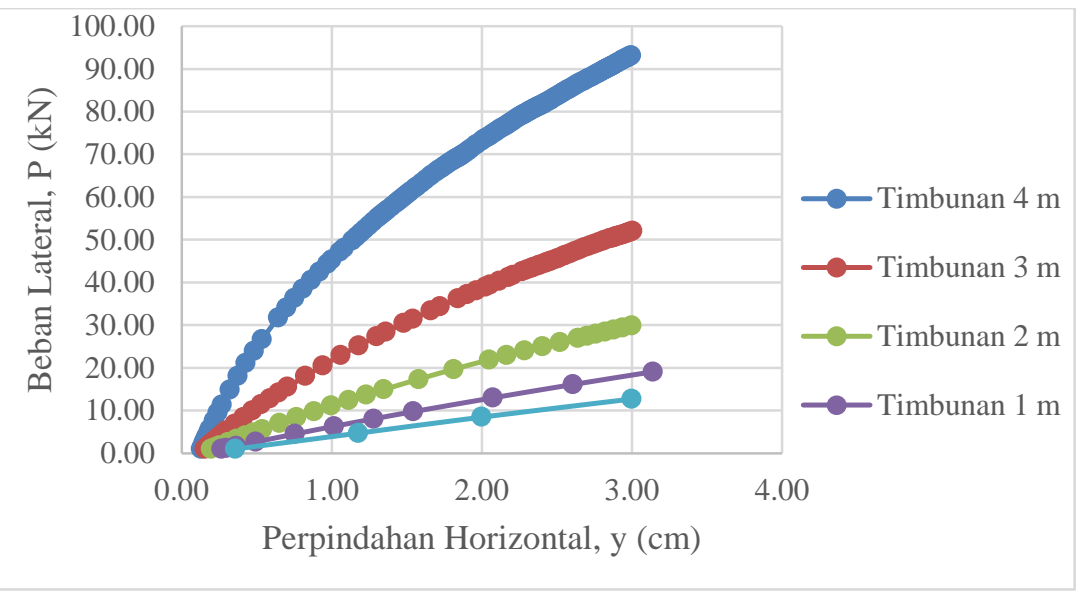

Gambar 4. Hubungan Beban dan Perpindahan Horizontal Tiang Zona B

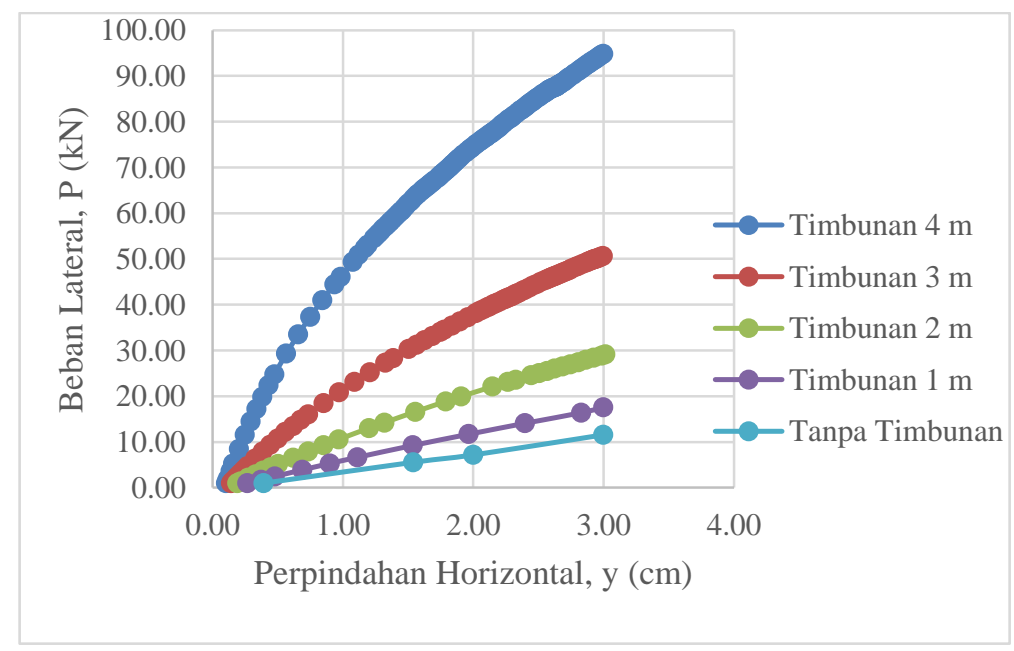

Gambar 5. Hubungan Beban dan Perpindahan Horizontal Tiang Zona C 


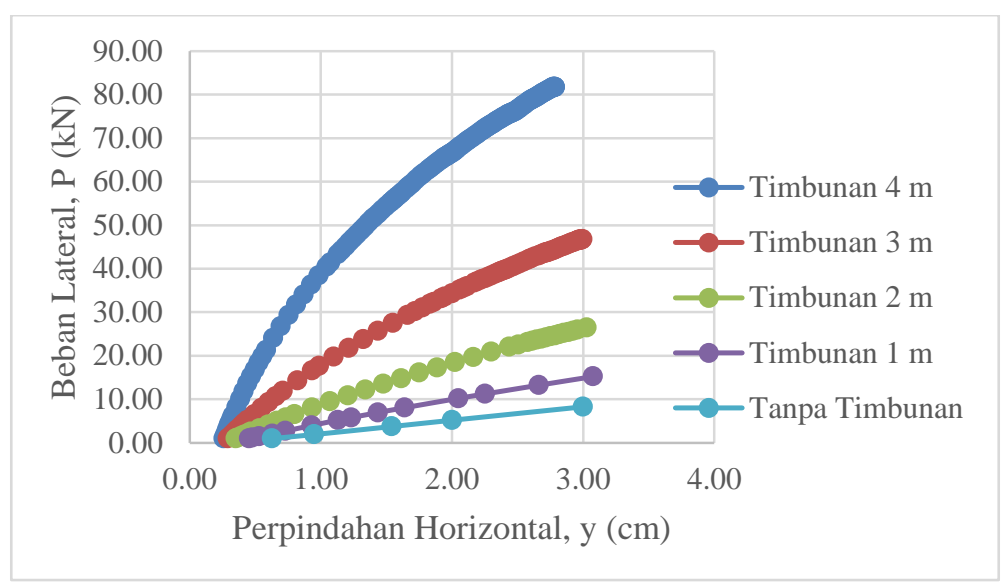

Gambar 6. Hubungan Beban dan Perpindahan Horizontal Zona D

\section{Kajian Teknis Momen Maksimum Tiang}

Pada kajian teknis momen maksimum tiang akan dikaji hubungan antara besar beban lateral dan momen maksimum yang terjadi untuk tiap tinggi timbunan pada tiap zona. Hubungan beban dan perpindahan horizontal tiap zona dapat dilihat pada Gambar 7. sampai Gambar 10.

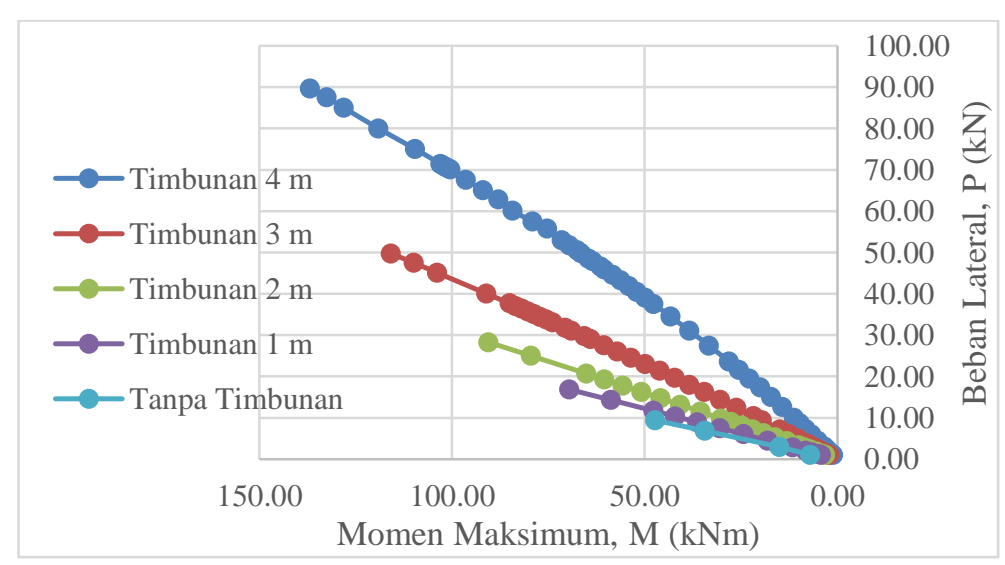

Gambar 7. Hubungan Beban dan Momen Maksimum Tiang Zona A

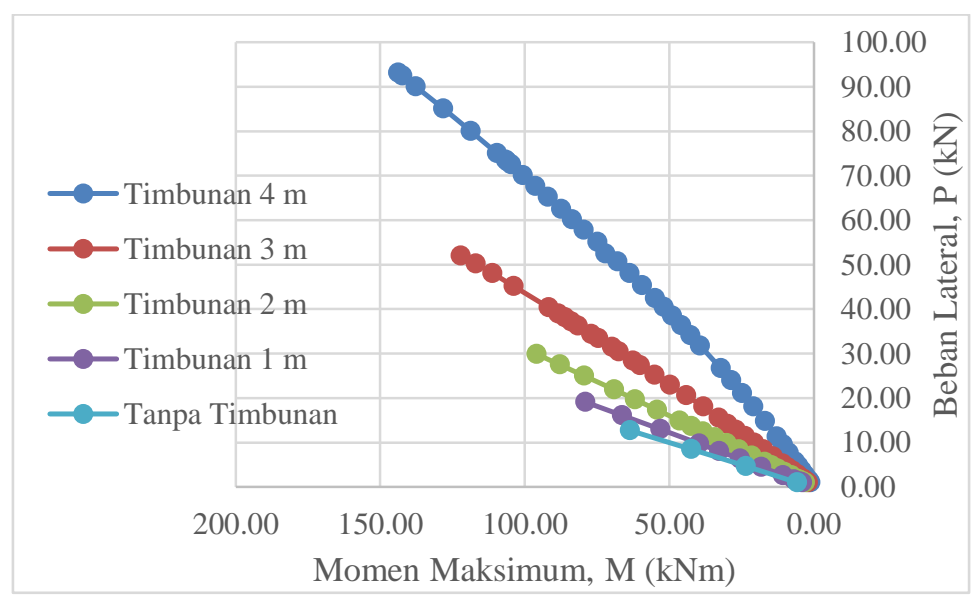

Gambar 8. Hubungan Beban dan Momen Maksmium Tiang Zona B 


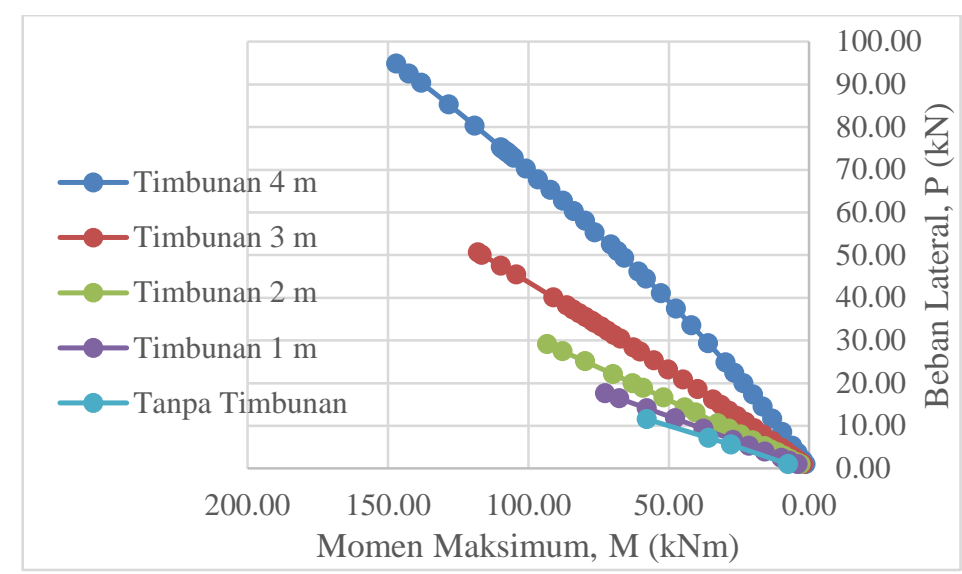

Gambar 9. Hubungan Beban dan Momen Maksimum Tiang Zona C

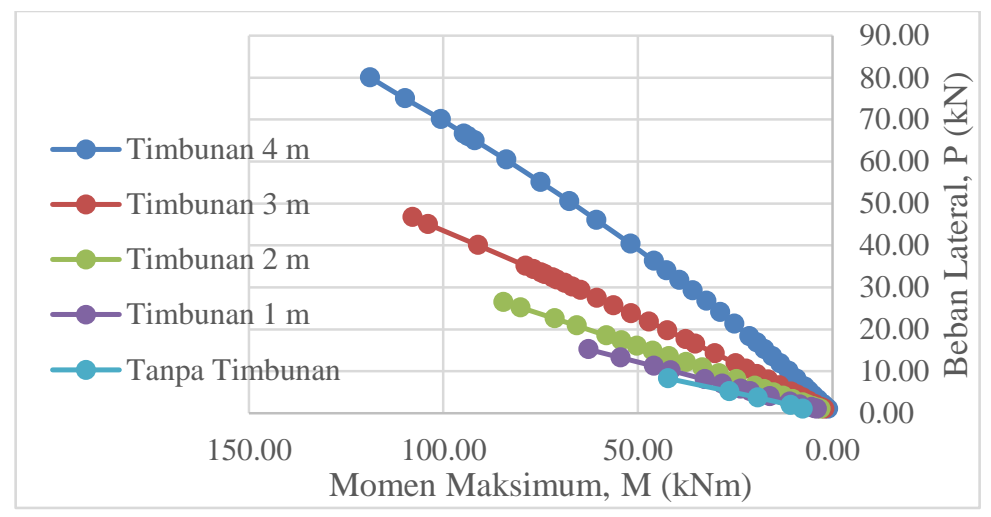

Gambar 10. Hubungan Beban dan Momen Maksimum Tiang Zona D

\section{Kajian Teknis Besar Beban Lateral dan Momen Maksimum untuk Berbagai Nilai Defleksi}

Kajian teknis mengenai besar gaya lateral dan momen maksimum mengkaji tentang besarnya gaya yang diperlukan untuk membuat tiang dapat mengalami defleksi sejauh $1 / 2$ “ dan 1 “ serta besar momen maksimum yang terjadi akibat beban tersebut. Proses analisis dilakukan dengan penarikan garis pada nilai defleksi $1 / 2$ " dan 1 " ke kurva beban dan perpindahan horizontal, sehingga akan didapatkan besarnya nilai beban lateral yang diperlukan untuk mengakibatkan defleksi tersebut. Setelah didapatkan beban lateral yang diperlukan dilakukan juga penarikan garis di kurva beban dan momen maksimum sehingga didapatkan nilai momen maksimum yang terjadi akibat beban lateral tersebut. Penentuan nilai beban lateral dan momen maksimum dapat dilihat di Gambar 11.
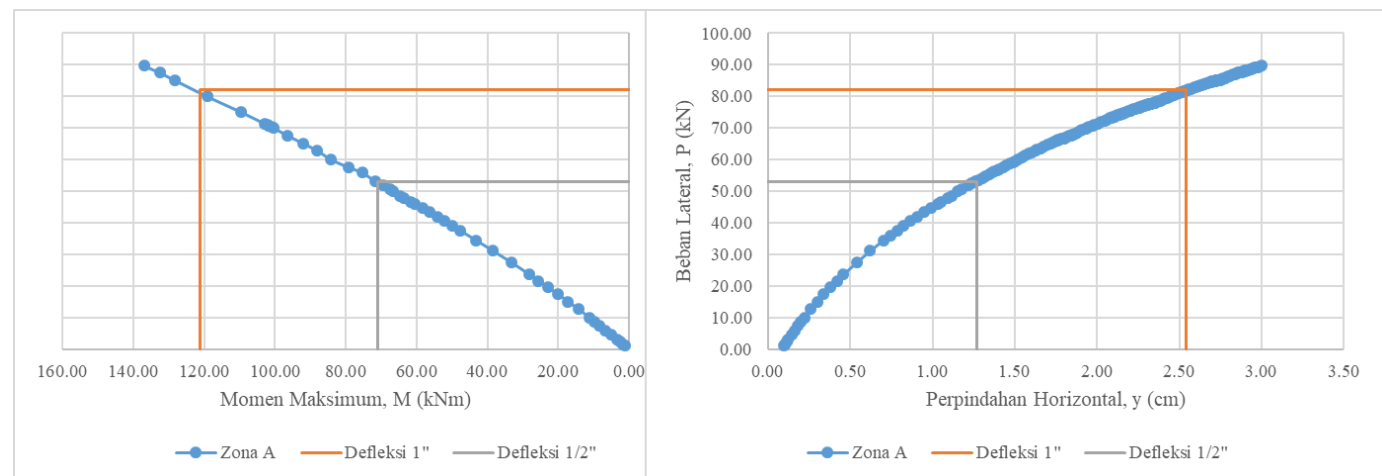

Gambar 11. Hubungan Perpindahan Horizontal, Beban, dan Momen Maksimum pada Timbunan 4 m di Zona A 
Berdasarkan penarikan pada kurva hubungan beban dan perpindahaan lateral serta beban dan momen maksimum didapat besarnya beban lateral yang dibutuhkan untuk mengakibatkan tiang mengalami perpindahan horizontal sejauh 1/2" dan 1" serta didapat juga momen maksimum yang terjadi pada tiang. Besarnya beban dan momen maksimum yang terjadi pada setiap zona dapat dilihat di Tabel 5. sampai Tabel 8.

Tabel 5. Besar Beban dan Momen Maksimum Akibat Berbagai Nilai Perpindahan Horizontal di Zona A

\begin{tabular}{ccccccccccc}
\hline $\begin{array}{c}\text { Perpindahan } \\
\text { Horizontal }\end{array}$ & \multicolumn{2}{c}{ Tanpa Timbunan } & \multicolumn{2}{c}{ Timbunan $1 \mathrm{~m}$} & \multicolumn{2}{c}{ Timbunan 2 m } & \multicolumn{2}{c}{ Timbunan 3 m } & \multicolumn{2}{c}{ Timbunan $4 \mathrm{~m}$} \\
\cline { 2 - 11 } & $\begin{array}{c}\mathrm{P} \\
(\mathrm{kN})\end{array}$ & $\begin{array}{c}\mathrm{M} \\
(\mathrm{kNm})\end{array}$ & $\begin{array}{c}\mathrm{P} \\
(\mathrm{kN})\end{array}$ & $\begin{array}{c}\mathrm{M} \\
(\mathrm{kNm})\end{array}$ & $\begin{array}{c}\mathrm{P} \\
(\mathrm{kN})\end{array}$ & $\begin{array}{c}\mathrm{M} \\
(\mathrm{kNm})\end{array}$ & $\begin{array}{c}\mathrm{P} \\
(\mathrm{kN})\end{array}$ & $\begin{array}{c}\mathrm{M} \\
(\mathrm{kNm})\end{array}$ & $\begin{array}{c}\mathrm{P} \\
(\mathrm{kN})\end{array}$ & $\begin{array}{c}\mathrm{M} \\
(\mathrm{kNm})\end{array}$ \\
\hline $1 / 2$ “ & 4.0 & 21 & 7.5 & 30 & 13.5 & 41 & 26.0 & 57 & 53.0 & 71 \\
1 “ & 8.1 & 41 & 14.0 & 57 & 25.0 & 80 & 45.0 & 103 & 82.0 & 121 \\
\hline
\end{tabular}

Tabel 6. Besar Beban dan Momen Maksimum Akibat Berbagai Nilai Perpindahan Horizontal di Zona B

\begin{tabular}{ccccccccccc}
\hline \multirow{2}{*}{$\begin{array}{c}\text { Perpindahan } \\
\text { Horizontal }\end{array}$} & \multicolumn{2}{c}{ Tanpa Timbunan } & \multicolumn{2}{c}{ Timbunan $1 \mathrm{~m}$} & \multicolumn{2}{c}{ Timbunan $2 \mathrm{~m}$} & \multicolumn{2}{c}{ Timbunan $3 \mathrm{~m}$} & \multicolumn{2}{c}{ Timbunan $4 \mathrm{~m}$} \\
\cline { 2 - 11 } & $\begin{array}{c}\mathrm{P} \\
(\mathrm{kN})\end{array}$ & $\begin{array}{c}\mathrm{M} \\
(\mathrm{kNm})\end{array}$ & $\begin{array}{c}\mathrm{P} \\
(\mathrm{kN})\end{array}$ & $\begin{array}{c}\mathrm{M} \\
(\mathrm{kNm})\end{array}$ & $\begin{array}{c}\mathrm{P} \\
(\mathrm{kN})\end{array}$ & $\begin{array}{c}\mathrm{M} \\
(\mathrm{kNm})\end{array}$ & $\begin{array}{c}\mathrm{P} \\
(\mathrm{kN})\end{array}$ & $\begin{array}{c}\mathrm{M} \\
(\mathrm{kNm})\end{array}$ & $\begin{array}{c}\mathrm{P} \\
(\mathrm{kN})\end{array}$ & $\begin{array}{c}\mathrm{M} \\
(\mathrm{kNm})\end{array}$ \\
\hline $1 / 2$ “ & 5.0 & 25 & 8.0 & 32 & 14.0 & 43 & 27.0 & 59 & 54.0 & 73 \\
1 “ & 10.7 & 53 & 15.7 & 64 & 26.0 & 83 & 46.0 & 105 & 85.0 & 127 \\
\hline
\end{tabular}

Tabel 7. Besar Beban dan Momen Maksimum Akibat Berbagai Nilai Perpindahan Horizontal di Zona C

\begin{tabular}{|c|c|c|c|c|c|c|c|c|c|c|}
\hline \multirow{2}{*}{$\begin{array}{c}\text { Perpindahan } \\
\text { Horizontal }\end{array}$} & \multicolumn{2}{|c|}{ Tanpa Timbunan } & \multicolumn{2}{|c|}{ Timbunan $1 \mathrm{~m}$} & \multicolumn{2}{|c|}{ Timbunan $2 \mathrm{~m}$} & \multicolumn{2}{|c|}{ Timbunan $3 \mathrm{~m}$} & \multicolumn{2}{|c|}{ Timbunan $4 \mathrm{~m}$} \\
\hline & $\begin{array}{c}\mathrm{P} \\
(\mathrm{kN})\end{array}$ & $\begin{array}{c}\mathrm{M} \\
(\mathrm{kNm})\end{array}$ & $\begin{array}{c}\mathrm{P} \\
(\mathrm{kN})\end{array}$ & $\begin{array}{c}\mathrm{M} \\
(\mathrm{kNm}) \\
\end{array}$ & $\begin{array}{c}\mathrm{P} \\
(\mathrm{kN}) \\
\end{array}$ & $\begin{array}{c}\mathrm{M} \\
(\mathrm{kNm})\end{array}$ & $\begin{array}{c}\mathrm{P} \\
(\mathrm{kN})\end{array}$ & $\begin{array}{c}\mathrm{M} \\
(\mathrm{kNm}) \\
\end{array}$ & $\begin{array}{c}\mathrm{P} \\
(\mathrm{kN})\end{array}$ & $\begin{array}{c}\mathrm{M} \\
(\mathrm{kNm})\end{array}$ \\
\hline $1 / 2 “$ & 4.5 & 23 & 7.5 & 30 & 13.5 & 41 & 26.0 & 57 & 55.0 & 75 \\
\hline 1 “ & 9.5 & 47 & 15.0 & 61 & 25.0 & 80 & 45.0 & 103 & 86.0 & 130 \\
\hline
\end{tabular}

Tabel 8. Besar Beban dan Momen Maksimum Akibat Berbagai Nilai Perpindahan Horizontal di Zona D

\begin{tabular}{ccccccccccc}
\hline $\begin{array}{c}\text { Perpindahan } \\
\text { Horizontal }\end{array}$ & \multicolumn{2}{c}{ Tanpa Timbunan } & \multicolumn{2}{c}{ Timbunan $1 \mathrm{~m}$} & \multicolumn{2}{c}{ Timbunan $2 \mathrm{~m}$} & \multicolumn{2}{c}{ Timbunan 3 m } & \multicolumn{2}{c}{ Timbunan $4 \mathrm{~m}$} \\
\cline { 2 - 11 } & $\begin{array}{c}\mathrm{P} \\
(\mathrm{kN})\end{array}$ & $\begin{array}{c}\mathrm{M} \\
(\mathrm{kNm})\end{array}$ & $\begin{array}{c}\mathrm{P} \\
(\mathrm{kN})\end{array}$ & $\begin{array}{c}\mathrm{M} \\
(\mathrm{kNm})\end{array}$ & $\begin{array}{c}\mathrm{P} \\
(\mathrm{kN})\end{array}$ & $\begin{array}{c}\mathrm{M} \\
(\mathrm{kNm})\end{array}$ & $\begin{array}{c}\mathrm{P} \\
(\mathrm{kN})\end{array}$ & $\begin{array}{c}\mathrm{M} \\
(\mathrm{kNm})\end{array}$ & $\begin{array}{c}\mathrm{P} \\
(\mathrm{kN})\end{array}$ & $\begin{array}{c}\mathrm{M} \\
(\mathrm{kNm})\end{array}$ \\
\hline $1 / 2$ “ & 3.0 & 16 & 6.0 & 25 & 11.5 & 35 & 23.0 & 50 & 48.0 & 65 \\
1 “ & 6.8 & 35 & 12.5 & 51 & 23.0 & 72 & 42.0 & 96 & 78.0 & 116 \\
\hline
\end{tabular}

\section{Kenaikan Tahanan Lateral}

Berdasarkan kajian teknis besar beban dan momen maksimum maka didapat persentase kenaikan tahanan lateral untuk setiap tinggi timbunan pada zona A, zona B, zona C, dan zona D seperti pada Tabel 9. sampai Tabel 12.

Tabel 9. Persentase Kenaikan Tahanan Lateral untuk Berbagai Tinggi Timbunan Zona A

\begin{tabular}{ccccc}
\hline Perpindahan & \multicolumn{4}{c}{ Persentase Kenaikan Tahanan Lateral (\%) } \\
\cline { 2 - 5 } Horizontal & Timbunan $1 \mathrm{~m}$ & Timbunan $2 \mathrm{~m}$ & Timbunan $3 \mathrm{~m}$ & Timbunan 4 m \\
\hline $1 / 2$ “ & 87.50 & 237.50 & 550.00 & 1225.00 \\
1 ““ & 72.84 & 208.64 & 455.56 & 912.35 \\
\hline
\end{tabular}

Tabel 10. Persentase Kenaikan Tahanan Lateral untuk Berbagai Tinggi Timbunan Zona B

\begin{tabular}{ccccc}
\hline Perpindahan & \multicolumn{4}{c}{ Persentase Kenaikan Tahanan Lateral (\%) } \\
\cline { 2 - 5 } Horizontal & Timbunan 1 $1 \mathrm{~T}$ & Timbunan 2 m & Timbunan 3 m & Timbunan 4 m \\
\hline $1 / 2$ “ & 60.00 & 180.00 & 440.00 & 980.00 \\
1 “ & 46.73 & 142.99 & 329.91 & 694.39 \\
\hline
\end{tabular}


Tabel 11. Persentase Kenaikan Tahanan Lateral untuk Berbagai Tinggi Timbunan Zona C

\begin{tabular}{ccccc}
\hline Perpindahan & \multicolumn{4}{c}{ Persentase Kenaikan Tahanan Lateral (\%) } \\
\cline { 2 - 5 } Horizontal & Timbunan $1 \mathrm{~m}$ & Timbunan $2 \mathrm{~m}$ & Timbunan $3 \mathrm{~m}$ & Timbunan 4 m \\
\hline $1 / 2$ “ & 66.67 & 200.00 & 477.78 & 1122.22 \\
1 “ & 57.89 & 163.16 & 373.68 & 805.26 \\
\hline
\end{tabular}

Tabel 12. Persentase Kenaikan Tahanan Lateral untuk Berbagai Tinggi Timbunan Zona D

\begin{tabular}{ccccc}
\hline Perpindahan & \multicolumn{4}{c}{ Persentase Kenaikan Tahanan Lateral (\%) } \\
\cline { 2 - 5 } Horizontal & Timbunan $1 \mathrm{~m}$ & Timbunan $2 \mathrm{~m}$ & Timbunan $3 \mathrm{~m}$ & Timbunan 4 m \\
\hline $1 / 2$ “ & 100.00 & 283.33 & 666.67 & 1500.00 \\
1 “ & 83.82 & 238.24 & 517.65 & 1047.06 \\
\hline
\end{tabular}

Grafik kenaikan tahanan lateral pada tiang dalam pemberian berbagai tinggi timbunan di setiap zona dapat dilihat di Gambar 12. dan Gambar 13.

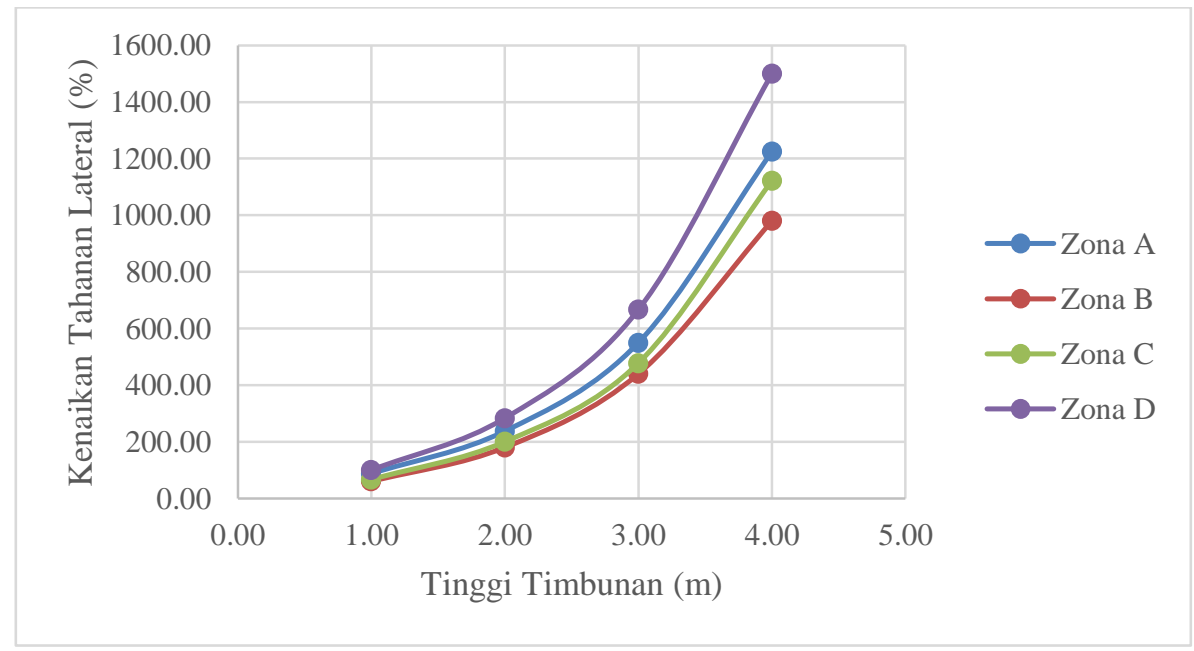

Gambar 12. Grafik Kenaikan Tahanan Lateral untuk Tiap Tinggi Timbunan Pada Nilai Perpindahan Horizontal 1/2”

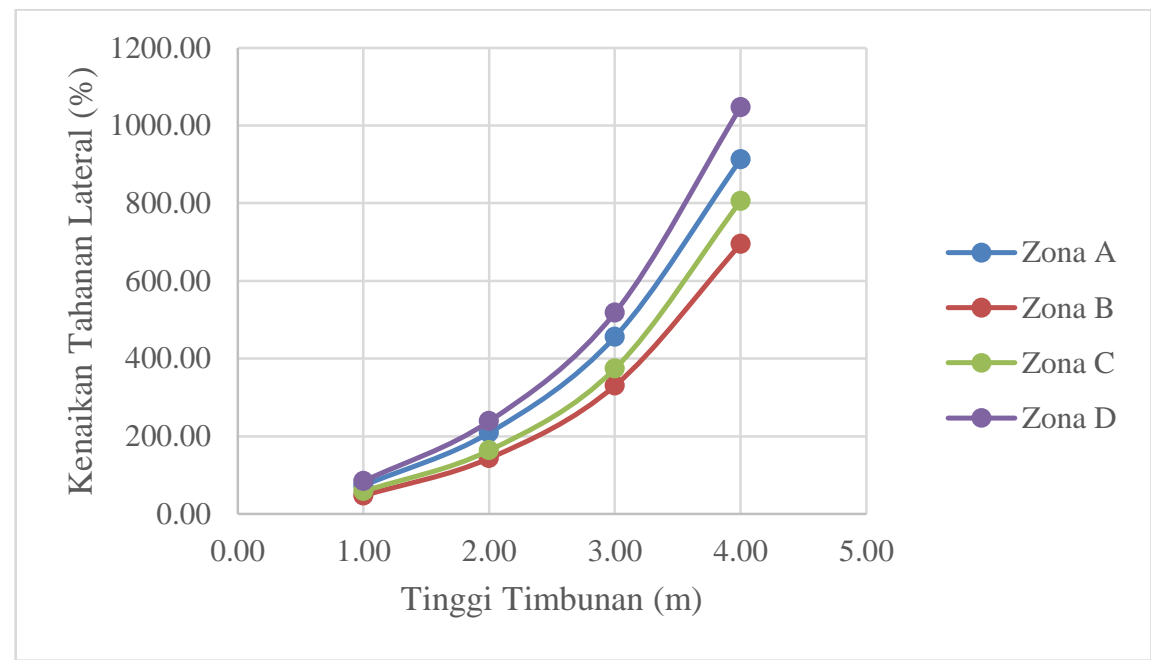

Gambar 13. Grafik Kenaikan Tahanan Lateral untuk Tiap Tinggi Timbunan Pada Nilai Perpindahan Horizontal 1" 


\section{KESIMPULAN}

Berdasarkan kajian teknis, analisis, dan pembahasan dari proyek jalan tol di Jakarta, dapat disimpulkan bahwa:

1. Konstruksi pile slab dengan timbunan setinggi $1 \mathrm{~m}$ sampai $4 \mathrm{~m}$ dapat memberikan tahanan lateral yang lebih besar dibandingkan dengan konstruksi pile slab tanpa timbunan

2. Konstruksi pile slab tanpa timbunan dapat memberikan tahanan lateral sebesar 3-5 $\mathrm{kN}$ untuk batasan perpindahan horizontal $1 \frac{1}{2}$ " dan sebesar $6.8-10.7 \mathrm{kN}$ untuk batasan perpindahan horizontal 1 “

3. Konstruksi pile slab dengan variasi timbunan setinggi $1 \mathrm{~m}$ sampai $4 \mathrm{~m}$ dapat memberikan tahanan lateral sebagai berikut:

- Timbunan $1 \mathrm{~m}$ : 6-8 $\mathrm{kN}$ untuk perpindahan horizontal $1 / 4^{\prime \prime}$ dan $12.5-15.7 \mathrm{kN}$ untuk perpindahan horizontal $1 / 2$ “"

- Timbunan $2 \mathrm{~m}$ : 11.5-14 $\mathrm{kN}$ untuk perpindahan horizontal 1/4“ dan 23-26 kN untuk perpindahan horizontal $1 / 2$ “"

- Timbunan $3 \mathrm{~m}$ : 23-27 $\mathrm{kN}$ untuk perpindahan horizontal 1/4" dan 42-46 $\mathrm{kN}$ untuk perpindahan horizontal $1 / 2$ “"

- Timbunan $4 \mathrm{~m}$ : 48-55 $\mathrm{kN}$ untuk perpindahan horizontal 1/4“ dan 78-86 kN untuk perpindahan horizontal $1 / 2$ “"

4. Konstruksi pile slab dengan variasi timbunan setinggi $1 \mathrm{~m}$ sampai $4 \mathrm{~m}$ dapat memberikan kenaikan tahanan lateral sebagai berikut:

- Timbunan $1 \mathrm{~m}$ : kenaikan tahanan lateral rata-rata $78.54 \%$ untuk defleksi $1 / 2$ " dan $65.32 \%$ untuk defleksi $1 "$

- Timbunan 2 m: kenaikan tahanan lateral rata-rata $225.21 \%$ untuk defleksi 1/2" dan $188.26 \%$ untuk defleksi 1"

- Timbunan 3 m: kenaikan tahanan lateral rata-rata 533.61\% untuk defleksi 1/2" dan 419.20\% untuk defleksi 1 ",

- Timbunan 4 m: kenaikan tahanan lateral rata-rata 1206.81\% untuk defleksi 1/2" dan $864.77 \%$ untuk defleksi 1"

5. Tiang pada konstruksi pile slab memiliki tahanan momen crack yang lebih besar dari semua momen yang diakibatkan akibat adanya beban lateral tanpa timbunan dan dengan adanya timbunan $1 \mathrm{~m}$ sampai $4 \mathrm{~m}$.

6. Zona D memiliki kenaikan tahanan lateral paling besar karena lapisan tanah zona D memiliki konsistensi tanah lebih rendah (medium stiff) dibandingkan dengan zona A, zona B, dan zona C (very stiff).

\section{DAFTAR PUSTAKA}

Coduto, Donald P., William A. Kitch, Man-chu Ronald Yeung. 2010. Foundation Design Principles and Practices. Rahardjo, Paulus P. 2017. Manual Pondasi Tiang. Edisi 5. Bandung : Universitas Katolik Parahyangan.

Peraturan Kepala Dinas P2B Prov. DKI Jakarta No. 50 Tahun 2007 Tentang Pedoman Perencanaan Struktur dan Geoteknik Bangunan.

Standar Nasional Indonesia 8460:2017 tentang Persyaratan Perancangan Geoteknik. 